\title{
MONITORING THE EFFECT OF QUARTZ-SAND REPLACEMENT BY AMORPHOUS-SILICA RAW MATERIAL ON THE MICROSTRUCTURE OF CALCIUM SILICATE COMPOSITES
}

\author{
OPAZOVANJE UČINKA ZAMENJAVE KREMENČEVEGA PESKA S \\ SUROVIM AMORFNIM SILIKATOM NA MIKROSTRUKTURO \\ KALCIJ-SILIKATNIH KOMPOZITOV
}

\author{
Jana Húšt’avová, Vít Černý", Rostislav Drochytka \\ Brno University of Technology, Faculty of Civil Engineering, Veveri 331/95, 60200 Brno, Czech Republic \\ Prejem rokopisa - received: 2019-08-19; sprejem za objavo - accepted for publication: 2019-11-04
}

doi:10.17222/mit.2019.191

\begin{abstract}
Quartz sand is the main raw material for the production of autoclaved calcium silicate composites. However, its resources are rapidly dwindling and alternative siliceous raw materials need to be sought and tested for replacement. Most often, they are raw materials containing amorphous silica. Amorphous silica is more readily soluble than crystalline silica and may thus contribute to the formation of a superior microstructure of the calcium silicate composite through calcium hydrate phases. This paper is focused on determining the optimal replacement rate of the amorphous-silica raw material replacing the crystalline silica sand, while describing changes in the microstructure of calcium silicate composites. The replacement was graded at $(0,25,50,75$ and 100) $\%$. Hydrothermal-treatment conditions were based on a real production of autoclaved aerated concrete, so a temperature of $190{ }^{\circ} \mathrm{C}$ and an isothermal holding time of $7 \mathrm{~h}$ were chosen. To study the effect of the ratio of raw materials on the microstructure, an X-ray diffraction analysis supported by scanning-electron-microscopy images was used.

Keywords: calcium silicate composite, glass, tobermorite
\end{abstract}

Kremenčev pesek je glavna osnovna surovina za izdelavo kalcij-silikatnih (Ca-Si) kompozitov v avtoklavih. Ker pa njegova najdišča hitro izginjajo, je potrebno za njegovo zamenjavo najti in preiskati alternativne surovine na osnovi silikatov. Najpogostejše osnovne surovine vsebujejo amorfni kremen. Ta je lažje topen kot kristalinični in tako prispeva k tvorbi boljše mikrostrukture Ca-Si kompozita preko kalcij-hidratnih faz. Ta članek se osredotoča na opis določitve optimalnega razmerja zamenjave kristaliničnega kremenčevega peska z amorfnim kremenčevim peskom in s tem povezanimi spremembami mikrostrukture Ca-Si kompozitov. Izbrana razmerja so bila $(0,25,50,75$ in 100$) \%$. Izbrani pogoji hidrotermalne obdelave so temeljili na realni proizvodnji prezračenega cementa $\mathrm{v}$ avtoklavih, to je temperaturi $190{ }^{\circ} \mathrm{C}$ in izotermnem času zadrževanja $7 \mathrm{~h}$ na tej izbrani temperaturi. Vpliv na mikrostrukturo izdelanih kompozitov so študirali z rentgensko difrakcijo (XRD), podprto s posnetki, izdelanimi z vrstičnim elektronskim mikroskopom.

Ključne besede: kompozit na osnovi kalcijevega silikata, steklo, Ca-Si-hidratni mineral (tobermorit)

\section{INTRODUCTION}

Calcium silicate composites, such as autoclaved aerated concrete (AAC), are made from a silica component and lime, or other raw materials such as cement, gypsum and aluminium powder. Only siliceous raw materials and lime were used for this research; therefore, attention will be paid to the interaction of these raw materials.

The siliceous component, a natural source of the primary raw material, is most often found in the crystalline form. Crystalline silica $\left(\mathrm{SiO}_{2}\right)$ is poorly reactive and its interaction with lime $(\mathrm{CaO})$ is possible under hydrothermal conditions. The high pressure, temperature and presence of steam during the autoclaving of calcium silicate composites promote the solubility of crystalline $\mathrm{SiO}_{2}$, thereby reacting with lime and $\mathrm{H}_{2} \mathrm{O}$ to form new calcium hydrosilicate phases $(\mathrm{CSH})$. Tobermorite is considered an important $\mathrm{CSH}$ phase. Tobermorite

*Corresponding author's e-mail:

cerny.v@fce.vutbr.cz (Vít Černý) $\left(5 \mathrm{CaO} \cdot 6 \mathrm{SiO}_{2} \cdot 5 \mathrm{H}_{2} \mathrm{O}\right)$ represents functional binders in lime silicate materials. Its quantity and quality then define the resulting material properties. ${ }^{1-6}$

Secondary raw materials have been used in the production of lime-silicate composites for many years, in the process of research and application. However, most often these are ashes. ${ }^{3-5}$ Other, alternative secondary raw materials have been investigated so far on a smaller scale. For example, P. Walczak et al. ${ }^{6}$ focused on the possibility of using ground waste glass in the AAC technology. Their research suggests that glass has a potential for use in the AAC technology. Therefore, this paper focuses on the research of the influence of ground container glass. Glass as a raw material is more often used in cementitious composites. ${ }^{7,8}$

\section{Influence of the $\mathrm{SiO}_{2}$ morphology}

Secondary raw materials are often characterized by the content of amorphous $\mathrm{SiO}_{2}$. Amorphous $\mathrm{SiO}_{2}$ is more soluble than crystalline $\mathrm{SiO}_{2}$ and thus more reactive. S. Haastrup et al. ${ }^{9}$ describe the kinetics of a CSH gel 
Table 1: Basic characteristics of raw materials

\begin{tabular}{|c|c|c|c|c|c|c|c|}
\hline & $\begin{array}{l}\text { Bulk density } \\
\left(\mathrm{g} / \mathrm{cm}^{3}\right)\end{array}$ & $\begin{array}{l}\text { Specific surface } \\
\left(\mathrm{cm}^{2} / \mathrm{g}\right)\end{array}$ & $\begin{array}{l}\mathrm{SiO}_{2} \\
(\%)\end{array}$ & $\begin{array}{c}\mathrm{Al}_{2} \mathrm{O}_{3} \\
(\%)\end{array}$ & $\begin{array}{l}\mathrm{K}_{2} \mathrm{O} \\
(\%)\end{array}$ & $\begin{array}{l}\mathrm{Na}_{2} \mathrm{O} \\
(\%)\end{array}$ & $\begin{array}{c}\mathrm{Fe}_{2} \mathrm{O}_{3} \\
(\%)\end{array}$ \\
\hline \multirow{2}{*}{ Quartz sand } & \multirow{2}{*}{2.70} & 3080 & \multirow{2}{*}{92.91} & \multirow{2}{*}{2.53} & \multirow{2}{*}{1.53} & \multirow{2}{*}{0.70} & \multirow{2}{*}{0.84} \\
\hline & & 6080 & & & & & \\
\hline \multirow{2}{*}{ Glass } & \multirow{2}{*}{2.56} & 2930 & \multirow{2}{*}{69.73} & \multirow{2}{*}{1.76} & \multirow{2}{*}{0.88} & \multirow{2}{*}{12.20} & \multirow{2}{*}{0.41} \\
\hline & & 6160 & & & & & \\
\hline
\end{tabular}

formation from amorphous microsilica. The CSH phase formed at a molar ratio $\mathrm{Ca} / \mathrm{Si}<1$ corresponds to the structure of tobermorite. They also state that the solubility of silica indicates the rate of the reaction of $\mathrm{CaO}$ and $\mathrm{SiO}_{2}$. The CSH phase formed from crystalline $\mathrm{SiO}_{2}$ contains a high amount of $\mathrm{Ca}(\mathrm{OH})_{2}$, while the $\mathrm{CSH}$ formed from the reaction of amorphous $\mathrm{SiO}_{2}$ contains a high amount of $\mathrm{SiO}_{2} \cdot{ }^{13,14}$ The presence of $\mathrm{SiO}_{2}$ may slow down the crystallization of $\mathrm{CSH}$ into tobermorite. Consequently, when using crystalline $\mathrm{SiO}_{2}$, the reaction is slower, but it may lead to the formation of more crystalline tobermorite. J. Fleischhacker ${ }^{15}$ describes, in his work, that the use of amorphous microsilica in a limesilicate composite led to the formation of tobermorite only after a prolongation of the hydrothermal treatment to 16 hours and an increase in the $\mathrm{Ca} / \mathrm{Si}$ molar ratio to 1.0 , otherwise tobermorite was not detected.

Influence of the fineness of siliceous raw materials on the formation of tobermorite

The quartz grain size affects the rate of the formation of $\mathrm{CSH}$ phases and hence the amount or morphology of $\mathrm{CSH}^{10,11}$. S. Bernstein et al. ${ }^{10}$ investigated the effect of the quartz grain size on the formation of 1.13-nm tobermorite in the AAC technology. They examined the difference between grain sizes of $8 \mu \mathrm{m}$ and $16 \mu \mathrm{m}$. They found that the use of $8-\mu \mathrm{m}$ grains allowed a faster formation of tobermorite than $16-\mu \mathrm{m}$ grains. N. Isu et al. ${ }^{12}$ also found that finer quartz accelerated the formation of tobermorite, but also found that in the case of finer quartz, the crystallinity of tobermorite was lower than in the case of coarse quartz.

\section{EXPERIMENTAL PART}

The main aim of this paper is to understand the changes in the microstructure of the sand-lime composite due to the gradual substitution of sand with ground glass. Another aim is to monitor the changes in the microstructure as well as physical and mechanical changes of samples based on the change in the specific surface area.

\section{Raw materials}

The samples were made from lime and silica components. Quartz sand was used as the reference silica component, and ground container glass was used as the substitute raw material. Two fineness values were chosen; quartz sand and glass had similar fineness values. The fineness was chosen to be $3000 \mathrm{~cm}^{2} / \mathrm{g}$ and
$6100 \mathrm{~cm}^{2} / \mathrm{g}$. The basic characteristics of the raw materials are shown in Table 1. Glass substitutions were chosen on a scale of $0-100 \%$, namely $(0,25,50,75$ and 100) $\%$.

The particle size and distribution were determined using a Malvern Mastersizer 2000. The resulting particle distribution is shown in Figure 1.

\section{Sample preparation}

The lime and silica components were mixed to achieve the desired molar ratio of $\mathrm{Ca} / \mathrm{Si} 0.83$ based on a 1.1-nm tobermorite molar ratio. The dry mixture was carefully homogenized and then water was added to form a liquid consistency. The water coefficient of the dry mix $(w)$ ranged from $w=0.60$ to $0.80[-]$, with the coarser silica component being mixed with $w=$ $0.60-0.66$ and the finer silica component with $w=$ $0.73-0.8[-]$.

The liquid suspension was poured into molds of $20 \times 20 \times 100 \mathrm{~mm}$. After $24 \mathrm{~h}$, the samples were removed from the molds and subjected to a hydrothermal treatment in a laboratory autoclave at $190{ }^{\circ} \mathrm{C}$ for $7 \mathrm{~h}$. The conditions of autoclaving were based on a real production of AAC.

\section{Methods}

The basic physical and mechanical properties of the samples were determined, namely the bulk density and compressive strength, according to standard EN 206+A1 Concrete - Specification, performance, production and conformity.

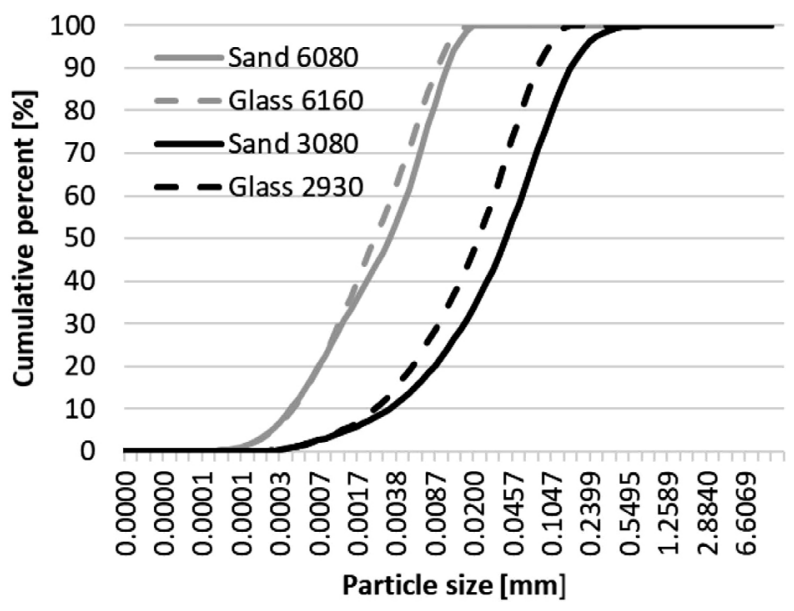

Figure 1: Granulometric curves of quartz sand and glass 
The microstructure study was performed using X-ray diffraction (XRD) and scanning electron microscopy (SEM). The clean cores of the samples were ground using a grinding mill to a size of $<0.5 \mathrm{~mm}$. The resulting powder was then ground in a McCrone mill to a particle size of $<20 \mu \mathrm{m}$, in an isopropanol solution with a standard addition, to more accurately determine the amounts of minerals. Calcium fluoride $\left(\mathrm{CaF}_{2}\right)$ was chosen as the standard. The resulting suspension was dried in a drying room to a steady weight. The sample thus prepared was loaded into an Empyrean Panalytical machine for an XRD analysis.

\section{RESULTS}

\section{Physical/mechanical properties}

The influence of the amount of the glass substituting the sand was investigated, while the influence of the fineness of the siliceous raw material on the basic physical/mechanical properties was studied. The emphasis was placed on the compressive strength.

The bulk density of the samples (Figure 2) with a fineness of $3000 \mathrm{~cm}^{2} / \mathrm{g}$ of the silica input component is, according to the results, unchanged with respect to the glass amount substituting the sand. Differences in the bulk-density values are within $5 \%$. The bulk-density difference for the samples with a fineness of $6100 \mathrm{~cm}^{2} / \mathrm{g}$ is already around $7 \%$, while the highest values are achieved by the samples with a 100- $\%$ glass substitution of the sand.

With respect to the compressive-strength values, some dependence on the glass substitution of the sand was observed for the samples with a $3000-\mathrm{cm}^{2} / \mathrm{g}$ silica fineness (Figure 3). The reference strength was the highest. Then the strength gradually decreased with the increasing glass substitution of the sand. The sample with a 50-\% substitution achieved only half the value of the compressive strength of the reference sample. Further, there was only a slight increase with the increasing glass-to-sand ratio of a sample. The samples with the siliceous raw material with a fineness of

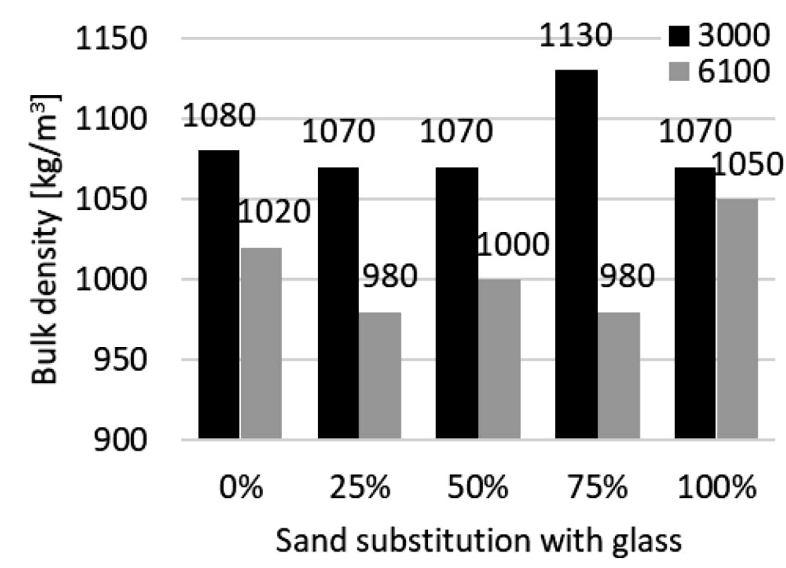

Figure 2: Bulk density of the samples

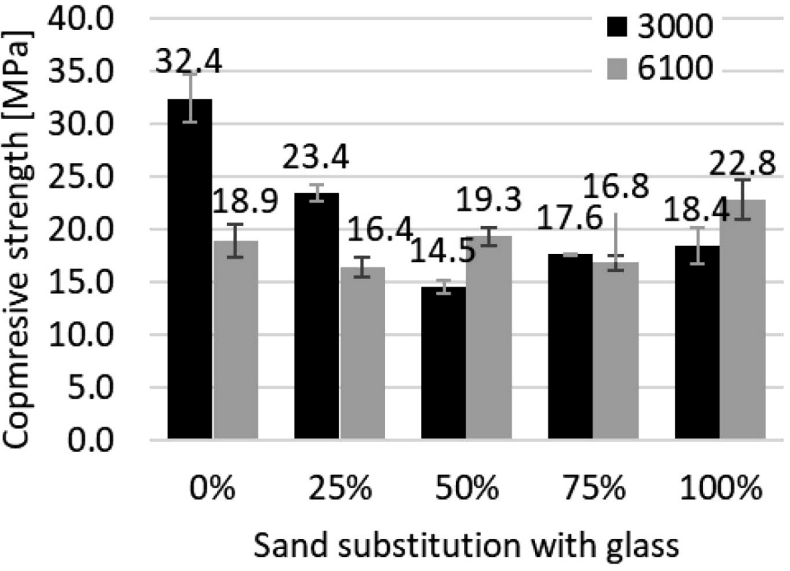

Figure 3: Compressive strength of the samples

$6100 \mathrm{~cm}^{2} / \mathrm{g}$ achieved a relatively constant strength without the influence of the amount of the glass substitution of the sand.

\section{Microstructure}

The data from diffractograms were evaluated according to the intensity and position of diffraction lines, but also according to Ritveld refinement of the contained tobermorite. The quantitative analysis was considered a priority of this paper. The results were supported by SEM images.

Diffraction lines of 1.1-nm tobermorite were detected in all samples. Further, quartz, orthoclase, calcite, a $\mathrm{CaF}_{2}$ addition and amorphous phases were detected. The intensity of the tobermorite diffraction lines (Figure 4) varied depending on the amount of glass and the fineness of the silica component. The changes were not constant. The reference sample with the coarser silica raw material achieved a high-intensity diffraction line. Then, with the $25-\%$ substitution, the intensity decreased and with $50-\%, 70-\%$ and $100-\%$ glass amounts, there was a
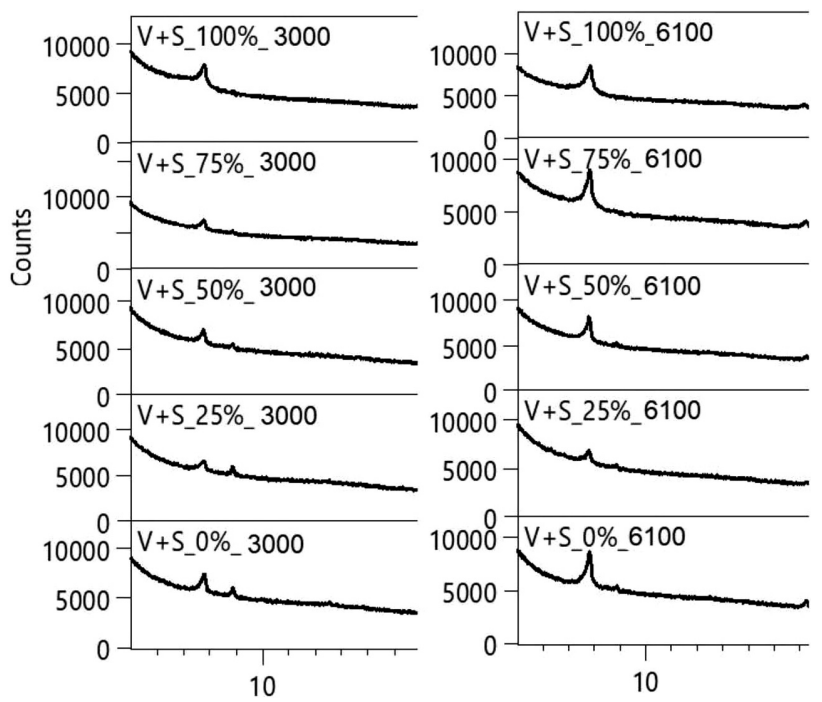

Figure 4: XRD diffractograms - isolated tobermorite diffraction lines 
J. HÚŠŤAVOVÁ et al.: MONITORING THE EFFECT OF QUARTZ-SAND REPLACEMENT BY AMORPHOUS-SILICA ...

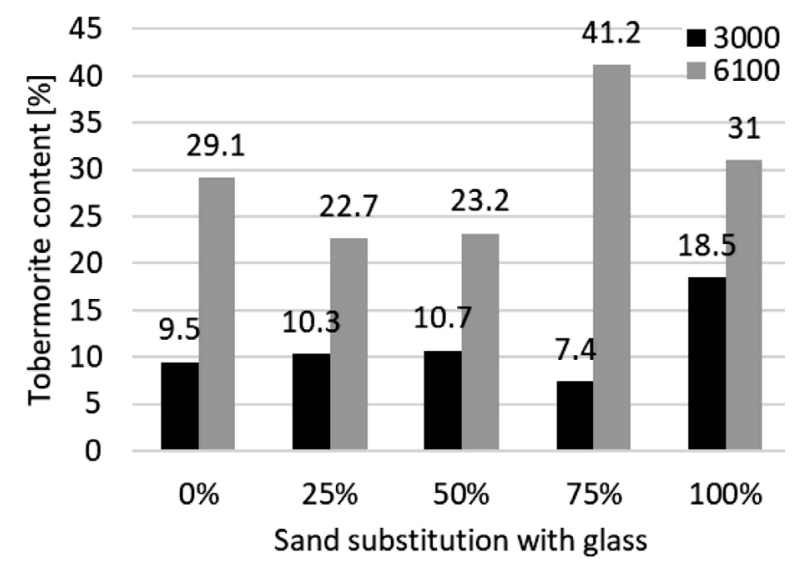

Figure 5: Tobermorite contents in the samples

gradual increase. Intensities were detected in the samples with a finer raw material, but for the sample with a $100-\%$ glass amount, it decreased again. Lastly, an increase in the intensity of the tobermorite diffraction line was observed with an increased specific surface area of the siliceous raw material.

The quantitative XRD analysis gave interesting results. The samples with a basic fineness of $3000 \mathrm{~cm}^{2} / \mathrm{g}$ up to a glass content of $75 \%$ did not show any significant change in the amount of tobermorite. However, the $100-\%$ substitution caused an increase in the amount of tobermorite by almost $100 \%$ compared to the reference sample. Another significant difference in the amount of tobermorite was observed due to different fineness values of the siliceous raw materials. The samples with a finer silica component generally contained 12-34\% more tobermorite. The largest amount of tobermorite was found in the sample with the $75-\%$ glass amount and with a fineness of $6500 \mathrm{~cm}^{2} / \mathrm{g}$.

\section{Scanning electron microscopy}

In the paper, SEM images of the samples with 0, 50 and $100 \%$ of glass are presented to show the nature of the change in the morphology of tobermorite.
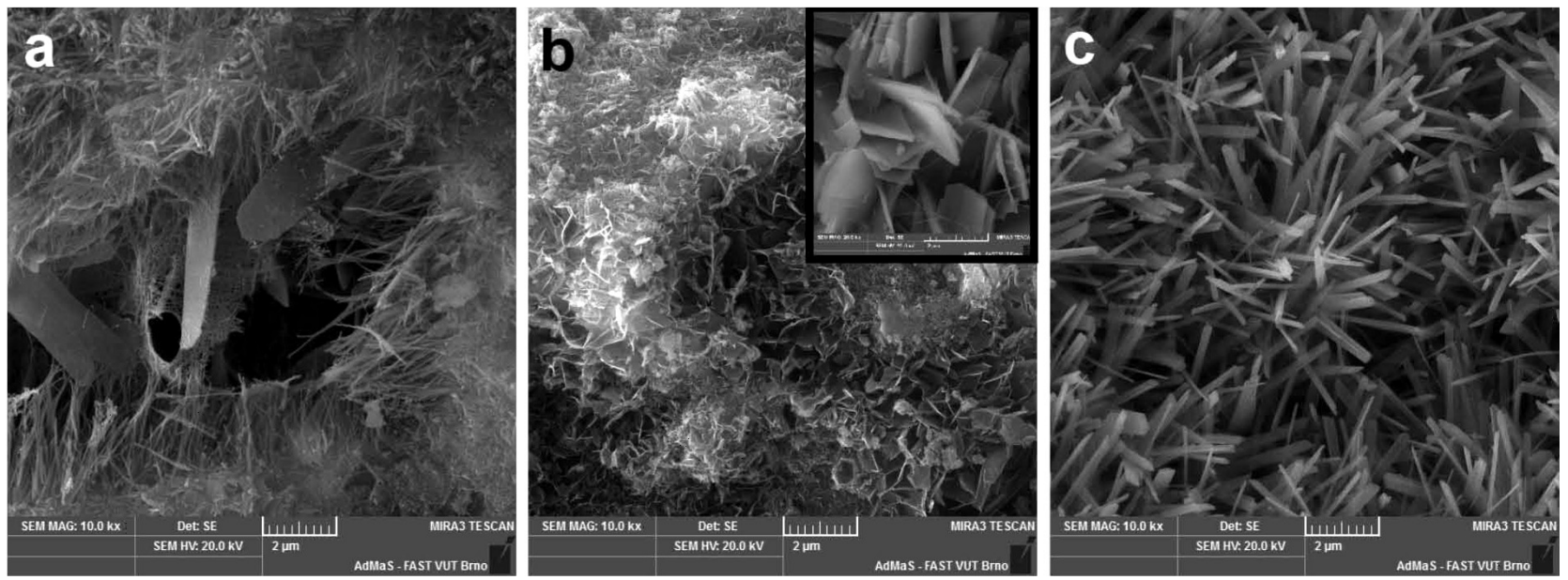

Figure 6: SEM images magnified 10k $x$ - samples with a fineness of $3000 \mathrm{~cm}^{2} / \mathrm{g}$ : a) sample with $0 \%$ of glass, b) sample with $50 \%$ of glass, c) sample with $100 \%$ of glass
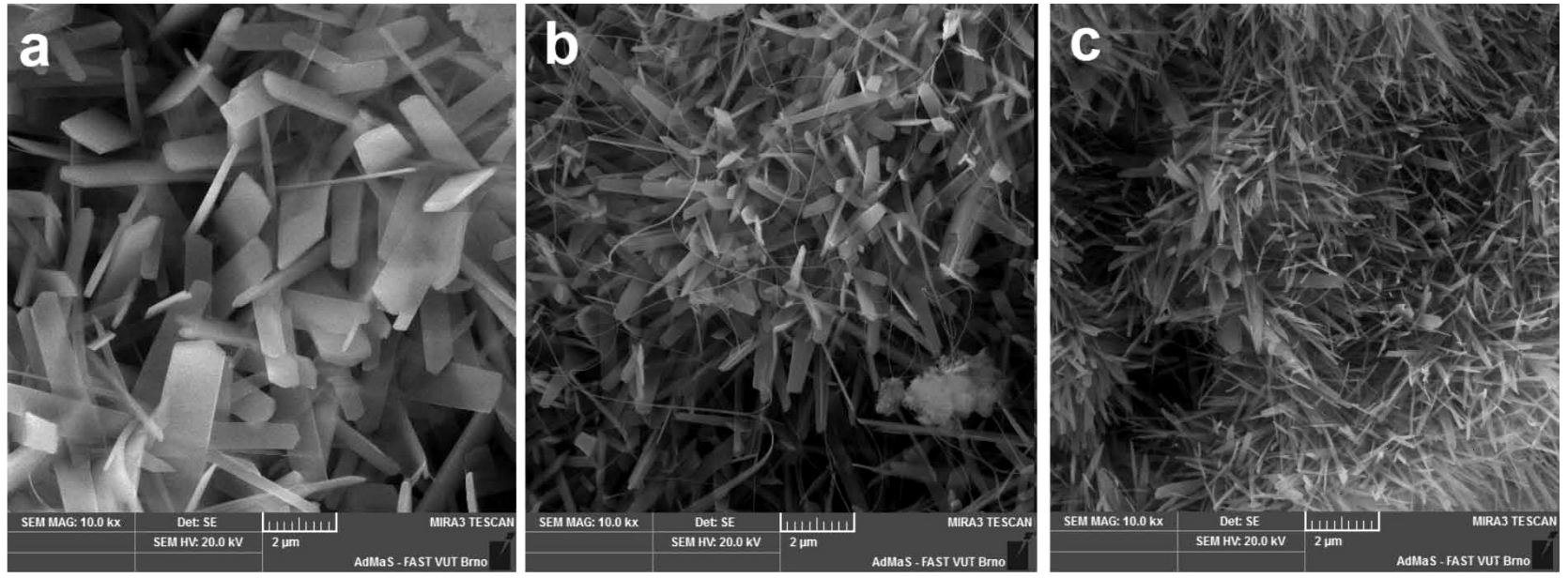

Figure 7: SEM images magnified 10k $\times$ - samples with a fineness of $6100 \mathrm{~cm}^{2} / \mathrm{g}:$ a) sample with $0 \%$ of glass, b) sample with $50 \%$ of glass, c) sample with $100 \%$ of glass 
For both fineness values used, the change in the morphology of tobermorite crystals depends on the amount of glass in the sample. Among the samples with a specific surface area of the silica raw material of $3000 \mathrm{~cm}^{2} / \mathrm{g}$ (Figure 6), the sample with $0 \%$ of glass includes thick tobermorite crystals and a CSH gel connecting the aggregate grains as the binder. There are already two types of tobermorite morphology in the sample with $50 \%$ of glass, in the form of thick plates and in the form of a "house of cards". In the 100-\% glass sample, small and thin tobermorite crystals are evenly crystallized over the entire amorphous grain surface.

A comparison of the samples with the fineness values of silica material of $3000 \mathrm{~cm}^{2} / \mathrm{g}$ and $6100 \mathrm{~cm}^{2} / \mathrm{g}$ shows a change in the morphology of tobermorite (Figure 7). In the image of the sample with $0 \%$ of glass and a higher fineness of the siliceous raw material, very well developed tobermorite crystals are visible, which are gradually smaller with an increasing amount of glass in the sample.

\section{DISCUSSION}

The use of glass as the substitute for silica sand had a significant effect on the resulting compressive strength of the samples, considering the basic fineness value of $3000 \mathrm{~cm}^{2} / \mathrm{g}$. According to the above results, it can be said that up to $50 \%$ of the glass substitution of the sand, the compressive strength decreases to almost half the strength of the reference lime-silicate composite. There may be several reasons for that. Although amorphous $\mathrm{SiO}_{2}$ is more reactive, the CSH phases resulting from amorphous $\mathrm{SiO}_{2}$ contain a higher $\mathrm{SiO}_{2}$ ratio, thereby slowing down the development of tobermorite crystals. ${ }^{13,14}$ Accordingly, there may be a lack of the binder phase interconnecting the aggregate grains in a sample. The results of the microstructure study support these assumptions. Changing the morphology of tobermorite is probably significant, as is the amount of tobermorite. Interestingly, the samples with a fineness of $6100 \mathrm{~cm}^{2} / \mathrm{g}$ of the siliceous raw material contain much more tobermorite than the samples with a fineness of $3000 \mathrm{~cm}^{2} / \mathrm{g}$, but this does not affect the resulting mechanical properties as expected. Nor does the morphology of tobermorite. Chucholowski et al. ${ }^{16}$ show that thicker crystals exhibit lower strengths than the crystals with the houseof-cards morphology. On the other hand, samples with well-developed tobermorite crystals achieve a higher compressive strength.

Regarding the effect of the specific surface area, it was found that finer raw materials support the formation of tobermorite with respect to both the quantity and morphology. Smaller grains of silica were probably more easily soluble and more involved in the reaction of the resulting formation of $\mathrm{CSH}$ phases. On the other hand, it consumed the portion of the filler that is essential for the resulting strength of the sample, causing a decrease in the compressive strength.

\section{CONCLUSIONS}

The paper deals with the influence of ground glass on the properties of a lime-silicate composite and, at the same time, it investigates the influence of the specific surface area of the raw material.

From the acquired knowledge, the following can be determined:

The presence of ground glass promotes the formation of tobermorite, especially its amount in a sample; however, at the same time, it reduces the compressive strength of the sample.

$25 \%$ is considered the maximum sand replacement. This substitution resulted in the lowest compressive strength of the sample. In the future, it would be interesting to verify the levels of substitution from $0 \%$ to $25 \%$.

The presence of crystalline $\mathrm{SiO}_{2}$ was found to be important for the filler function. Nevertheless, it is possible to completely substitute the crystalline raw material with glass, but only if the lower compressive strengths are satisfactory.

Increasing the specific surface area from $3000 \mathrm{~cm}^{2} / \mathrm{g}$ to $6100 \mathrm{~cm}^{2} / \mathrm{g}$ resulted in a significant increase in the amount of tobermorite in the sample. At the same time, the compressive strength, which was constant, was reduced and the glass substitution had no effect. This finding leads to the conclusion that a high fineness of the raw material is desirable if tobermorite is to be synthesized. In the case of the physical/mechanical properties of a calcium silicate composite, this appears to be unprofitable.

\section{Acknowledgment}

This paper was written within the project of the Czech Science Foundation (GACR), with identification code GA17-14198S, "Kinetics of silicon microstructure formation in dependence of hydrothermal conditions and type of used materials", and was also funded within the project with code FAST-J-19-6029, "Study of tobermorite to create a comparative database for understanding the changes in the microstructure of lime-silicate composites".

\section{REFERENCES}

${ }^{1}$ N. Narayanan, K. Ramamurpthy, Microstructural investigations on aerated concrete, Cement and Concrete Research, 30 (2000) 3, 457-464, doi:10.1016/S0008-8846(00)00199-X

${ }^{2}$ R. Drochytka, Pórobeton, Brno: VUTIUM, 1999

${ }^{3}$ H. Kurama, İ. B. Topçu, C. Karakurt, Properties of the autoclaved aerated concrete produced from coal bottom ash, Journal of Materials Processing Technology, 209 (2009), 767-773, doi:10.1016/ j.jmatprotec.2008.02.044 


\section{J. HÚŠŤAVOVÁ et al.: MONITORING THE EFFECT OF QUARTZ-SAND REPLACEMENT BY AMORPHOUS-SILICA ...}

${ }^{4}$ P. Walczak, P. Szymański, A. Różycka, Autoclaved Aerated Concrete Based on Fly Ash in Density $350 \mathrm{~kg} / \mathrm{m}^{3}$ as an Environmentally Friendly Material for Energy - Efficient Constructions, Procedia Engineering, 122 (2015), 39-46, doi:10.1016/j.proeng.2015.10.005

${ }^{5}$ Y. Song, Ch. Guo, J. Qian, T. Ding, Effect of the Ca-to-Si ratio on the properties of autoclaved aerated concrete containing coal fly ash from circulating fluidized bed combustion boiler, Construction and Building Materials, 83 (2015), 136-142, doi:10.1016/j.conbuildmat. 2015.02.077

${ }^{6}$ P. Walczak, J. Małolepszy, M. Reben, P. SzymańskI, K. Rzepa, Utilization of Waste Glass in Autoclaved Aerated Concrete, Procedia Engineering, 122 (2015), 302-309, doi:10.1016/j.proeng.2015. 10.040

${ }^{7}$ K. Goropse, E. Booya, H. Ghaednia, S. Das, Effect of various glass aggregates on the shrinkage and expansion of cement mortar, Construction and Building Materials, 210 (2019), 301-311, doi:10.1016/ j.conbuildmat.2019.03.192

${ }^{8}$ H. Lee, A. Hanif, M. Usman, J. Sim, H. Oh, Performance evaluation of concrete incorporating glass powder and glass sludge wastes as supplementary cementing material, Journal of Cleaner Production, 170 (2018), 683-693, doi:10.1016/j.jclepro.2017.09.133

${ }^{9}$ S. Haastrup, M. S. Bødker, S. R. Hansen, D. Yu, Y. Yue, Impact of amorphous micro silica on the C-S-H phase formation in porous calcium silicates, Journal of Non-Crystalline Solids, 481 (2018), 556-561, doi:10.1016/j.jnoncrysol.2017.11.051

${ }^{10} \mathrm{~S}$. Bernstein, K. T. Fehr, The formation of $1.13 \mathrm{~nm}$ tobermorite under hydrothermal conditions: 1 . The influence of quartz grain size within the system CaO-SiO2-D2O, Progress in Crystal Growth and
Characterization of Materials, 58 (2012), 84-91, doi:10.1016/ j.pcrysgrow.2012.02.006

${ }^{11}$ J. Kikuma, M. Tsunashima, T. Ishikawa, S. Matsuno, A. Ogawa, K. Matsui, M. Sato, Effects of quartz particle size and water-to-solid ratio on hydrothermal synthesis of tobermorite studied by in-situ time-resolved X-ray diffraction, Journal of Solid State Chemistry, 184 (2011), 2066-2074, doi:10.1016/j.jssc.2011.05.061

${ }^{12}$ N. Isu, H. Ishida, T. Mitsuda, Influence of quartz particle size on the chemical and mechanical properties of autoclaved aerated concrete (I) tobermorite formation, Cement and Concrete Research, 25 (1995), 242-248, doi:10.1016/0008-8846(95)00003-8

${ }^{13}$ R. Siauciunas, A. Baltusnikas, Influence of $\mathrm{SiO} 2$ modification on hydrogarnets formation during hydrothermal synthesis, Cement and Concrete Research, 33 (2003), 1789-1793, doi:10.1016/S00088846(03)00200-X

${ }^{14}$ N. Y. Mostafa, S. A. S. El-Hemaly, E. I. Al-Wakeel, S. A. El-Korashy, P. W. Brown, Activity of silica fume and dealuminated kaolin at different temperatures, Cement and Concrete Research, 31 (2001), 905-911, doi:10.1016/S0008-8846(01)00489-6

${ }^{15} \mathrm{~J}$. Fleischhacker, The effect of fly ash aerated concrete production technology for the formation of tobermoritic phases, Diploma Thesis, Brno University of Technology, Faculty of Civil Engineering, Brno 2016, 103

${ }^{16}$ C. Chucholowski, M. Holger, K. Thienel, Improving the recyclability, environmental compatibility, and $\mathrm{CO}_{2}$ balance of autoclaved aerated concrete by replacing sulfate carrier and cement with calcined clays, Ce/papers, 2 (2018), 503-512, doi:10.1002/cepa.846 